\title{
RISING INEQUALITY AND
}

\section{THE FINANCIAL CRISES OF 1929 AND 2008}

\author{
Jon D. Wisman and Barton Baker \\ “...in any community in which class distinctions are somewhat \\ vague, all canons of reputability and decency, and all standards of \\ consumption, are traced back by insensible gradations to the \\ usages and habits of thoughts of the highest social and pecuniary \\ class” (Veblen 1899: 104)
}

"Speculators may do no harm as bubbles on a steady steam of enterprise. But the position is serious when enterprise becomes a bubble on a whirlpool of speculation” (Keynes 1936: 159).

"The class which has the means of material production at its disposal, has control at the same time over the means of mental production, so that thereby, generally speaking, the ideas of those who lack the means of mental production are subject to it” (Marx 1846).

ABSTRACT: Inequality increased dramatically in the decades leading up to the financial crises of both 1929 and 2008. Yet students of both crises have largely ignored any role that rising 
inequality might have played in rendering the financial sector more vulnerable to systemic dysfunction. This study draws upon the work of Thorstein Veblen, Michal Kalecki, and Karl Marx to clarify the manner in which growing inequality prior to both crises made U.S. financial markets more prone to systemic dysfunction. Greater inequality generated three dynamics that heightened conditions in which these financial crises might occur. The first is that greater inequality meant that individuals were forced to struggle harder to find ways to consume more to maintain their relative social status, thereby reducing their savings and increasing their indebtedness. The second is that holding ever greater income and wealth, the elite flooded financial markets with credit, helping keep interest rates low and encouraging the creation of new credit instruments. The third dynamic is that, as the rich took larger shares of income and wealth, they gained more command over ideology and hence politics. Reducing the size of government, tax cuts for the rich, deregulating the economy, and failing to regulate newly evolving credit instruments flowed out of this ideology.

The financial crisis of 2008 has prompted research into its commonalities with that of 1929 and a search for common causes. Most scholars agree that in both instances low interest rates, financial innovation, and laissez-faire ideology supporting lax regulation played important causal roles. While this analysis is not incorrect, it addresses proximate as opposed to more profound underlying causality. At this deeper level, both crises were in part caused by the consequences of dramatically rising inequality.

There were many differences in the economies that led up to the crises of 1929 and 2008. For instance, in 1929, the federal government constituted only about three percent of GDP versus about 22 percent in 2008. Whereas extreme speculation on the eve of the current crisis was most 
visible in the real estate market, it was in the stock market in the late 1920s. Yet beneath such differences were striking similarities.

In both periods, union membership substantially declined, undermining the bargaining power of workers; taxes on the rich were cut significantly; income and wealth distribution became radically more unequal, forcing households to struggle ever-harder to maintain their relative social status, their social respectability; an elite had ever-rising funds to invest, but because everyone else had smaller shares to spend, investment potential was greater in the financial than the production sector, stimulating innovations in credit instruments; and real estate bubbles were critical to both crises.

In both periods, a wealthy elite's possession of an ever-rising share of society’s resources enabled their increasing command over political ideology, often diverting attention from economic to cultural issues. As cultural wars divided the electorate in the post-Reagan era, so too the 1920s saw political combat over such issues as evolution, prohibition, immigration, and the increasingly militant Klu Klux Klan.

But of all the similarities, what was causally most important in setting the stage for both crises was a dramatic rise in inequality. Inequality during the preludes to both crises reached unparalleled extremes for the 80-year period in which they occurred. Yet students of both crises have largely ignored any role that rising inequality might have played in rendering the financial sector more vulnerable to systemic dysfunction. ${ }^{1}$

Although the analysis developed in this paper fits into the Keynesian/Kaleckian underconsumptionist school, it enriches that perspective by drawing upon Thorstein Veblen's theory of consumer behavior and Karl Marx’s theory of ideology formation to clarify the manner in which growing inequality prior to both crises made U.S. financial markets prone to 
dysfunction. Greater inequality generated three dynamics that heightened conditions in which these financial crises might occur. The first is that greater inequality meant that individuals were forced to struggle harder to find ways to consume more to maintain their relative social status, thereby decreasing their saving and augmenting their indebtedness. The second is that holding ever greater income and wealth, an elite flooded financial markets with credit, helping keep interest rates low and encouraging the creation of new credit instruments. The third dynamic is that, as the rich took larger shares of income and wealth, they gained more command over ideology and hence politics. Reducing the size of government, deregulating the economy, and failing to regulate newly evolving credit instruments flowed out of this ideology.

Financial crises have plagued capitalism since its beginning. Recovery was usually quick, mostly because the major consequence was the destruction of a great deal of paper wealth held by an elite. What distinguishes the crises of 1929 and 2008 is that the speculative mania preceding them occurred not only in stock markets, but in real estate markets as well. Real estate markets are more democratic than stock markets in that a larger share of the population participates in ownership, and thus a collapse of a speculative bubble in real estate has consequences that are far greater and potentially far longer lasting. Real estate ownership also possesses a social characteristic that is special: for most households it constitutes not only the most important store of wealth, but also the most important symbol of social status.

\section{Rising Inequality}

Since the Civil War, there have been three major explosions in inequality: the first between the end of the Civil War until about 1900; the second between World War I and the late 1920s; and the last between the 1970s and at least 2008. Both of the latter two ended in severe crises. 
The periods leading up to both crises appeared to be highly prosperous. Between 1922 and 1929, GNP grew at an annual rate of 4.7 percent and unemployment averaged 3.7 percent (White 1990: 69). Between 1993 and 2007,GNP growth averaged 3.25 percent (NIPA Tables), and unemployment averaged 5.2 percent (BLS). However, in both periods productivity gains outpaced wages, with important distributional consequences. As Long noted, “So large is labor's share of national income that any substantial disparity between productivity and real wages would exert great impact on the other shares - either largely expropriating them or presenting them with huge windfalls”(1960: 112). Accordingly, the share of total income received by the richest five percent of the population increased from 24.3 percent in 1919 to 33.5 percent in 1929. The disposable income of the top one percent of taxpayers rose 63 percent (Livingston 2009: 38). The number of millionaires increased from 7,000 in 1922 to 30,000 in 1929. (Phillips 2002: 11). The real prosperity of the 1920s was reserved for those residing in the top of the income scale (Bernstein, 1966; Stricker 1985). Contributing to this heightened inequality were tax Areforms@ that reduced corporate taxes and lowered the maximum personal income tax rate from 65 to 32 percent (Sobel 1968, 52-53).

Similarly, real disposable income declined for wage earners in the three decades leading up to 2008. Average weekly earnings (in 1982 dollars) declined from \$331.39 in 1973 to \$275.93 in 2005, greatly lagging behind productivity gains (Miringoff and Opdyke 2008: 226). What is especially striking about the two periods is the dramatically larger shares of income and wealth accruing to the ultra wealthy, especially the top one-hundredth of one percent (see Figure 1). Their income shares soared from about 1.7 to 5 percent in the first period, and from about 0.9 to 6 percent in the second. 
(Figure 1)

\section{Rising Inequality and the Struggle for Status Security}

In the U.S. since colonial times, there has been a widespread belief that vertical mobility is readily possible. Consequently, Americans have generally felt responsible for their own social status. Through adequate dedication and effort, anyone can move up, even to the very highest rungs of social status. Ones social status is not given, but earned.

However, how hard one works in modern societies is generally not directly observable. What more readily catches attention is how much one can consume, which can stand, more or less, as a proxy for how hard one has worked.Thus, because Americans believe they are individually responsible for their own social standing, they feel strongly compelled to demonstrate status and through consumption. Greater inequality means that consumers must stretch further to move up, or even maintain their relative social standing.

An attempt to maintain or increase social standing through consumption is what Veblen meant by conspicuous consumption. His theory of consumer behavior is founded upon the fact that social status is critically important to people and thus strongly affects their behavior. Ultimately underpinning social status or respectability is the need for self-esteem or self-respect, what John Rawls suggested to be “perhaps the most important primary good” such that without it nothing else has much value (1971: 440).

Where there is a strong belief that vertical mobility is possible, a substantial increase in inequality could be expected to prompt households to respond in one or more of three ways to 
maintain social standing: consume more and thus save less; become more indebted; or increase work hours. As the evidence presented below demonstrates, as a whole, U.S. households did two of the three during the 1920s and all three during the three decades leading up to 2008 as inequality increased.

\section{Automobiles, Houses, and Social Status}

The automobile industry expanded dramatically from the very beginning of the century up until 1929, when over four million vehicles were produced, a level not attained again until 1949. Two of every three families owned cars by 1929 (Livingston 1994: 108).

Arguably, no single new consumer good had heretofore more transformed society than the automobile. Not only was the automobile a symbol of status, it also helped fuel a housing boom by making suburban living more viable. Because suburban land was less expensive, housing could be in individual units as opposed to the multi-unit apartment buildings on more expensive in-town land. A detached house has far greater potential for revealing status than units encased within an apartment complex.

The importance of the automobile and free-standing houses as status symbols is such that both played critical roles in the struggle for status stability as inequality rose prior to both crises. The fundamental reason, as Wilkinson and Pickett point out, is that "research confirms that the tendency to look for goods which confer status and prestige is indeed stronger for things which are more visible to others” (2009: 225).

During the 1920s, as the wealthy took every larger shares of total income, they bought ever-more expensive houses, vacation properties, automobiles, country club memberships and other luxury items. ${ }^{2}$ Automobiles made possible the dramatic expansion of private playgrounds for the rich - so-called country clubs. The real estate boom was especially robust in vacation 
facilities such as hotels, tourist cottages, and motor courts (Grebler, et. al. 1956). This put intense pressure on all with lower incomes to consume more to maintain their relative social standing. ${ }^{3}$

The same basic scenario played out again over the three decades of rising inequality prior to the crisis of 2008. The struggle to keep up was especially intense in housing. As those at the pinnacle of wealth and income competed among themselves for status, they bought and had constructed ever-larger mansions, thereby degrading the status quality of homes owned or occupied by everyone beneath them. Because houses and cars are principal symbols of status, there was an explosion in the consumption of so-called McMansions and extremely expensive cars. In face of the intense competition to keep up, not surprisingly, a February 2008 Pew survey found that "the proportion of wealthy Americans who say they are very satisfied with their housing and cars ... has declined considerably since 2001” (Pew Research Center 2008). As the wealthiest Americans received ever-larger income shares and increased their consumption moreor-less proportionately, they reduced the subjective value of consumption levels below them. ${ }^{4}$

As inequality dramatically increased, the struggle by households to maintain their relative status resulted in reduced saving, ${ }^{5}$ greater indebtedness, and prior to 2008, more work hours for households. Personal saving as a percent of disposable income declined from 6.4 percent in the 1898-1916 period to 3.8 percent in the 1922-1929 period (Olney 1991: 48). In the decades before 2008, it fell from 10.4 percent in 1980-84, to 7.7 percent in 1985-89, to 6.5 percent in 1990-94, to 3.8 percent in 1995-99, to 2.1 percent in 2000-04; and became negative in 2005 and 2006 . In their struggle to maintain their relative status in face of rising inequality, Americans became more indebted. Debt as a percent of income increased from 4.64 percent in 1919 to 9.34 percent in 1929 (Olney 1991: 88-89). Total consumer debt, which was \$3 billion in 1920, rose to $\$ 7.2$ billion by 1929 (Bernstein 1998: 194). ${ }^{6}$ In the decades prior to 2008, average consumer 
household debt as a percent of income increased from 88 in 1989 to 150 in 2007 (Survey of Consumer Finances). Although this increased indebtedness held for households in all income quintiles, not unexpectedly, debt increased more for lower income groups.

This rise in indebtedness in both periods fits the Veblenian hypothesis that in a society in which vertical mobility is believed to be highly fluid, increasing gaps in income all along the spectrum stimulate everyone to struggle harder to meet their consumption status targets, ${ }^{7}$ as those at the very top compete among themselves for the very pinnacle of status. ${ }^{8}$

A third possible response of households in their struggle to maintain their relative social standing in the face of rising inequality is to work longer hours. Although the work week continued its contraction during the 1920s, Bernstein notes that "New expectations regarding appropriate family income levels... encouraged more women to enter the labor market” (1998: 195). In the later period, the increase in work hours is more striking. As inequality rose dramatically between 1970 and 2002, work hours per capita rose 20 percent in the U.S. By contrast, in the European Union where income inequality increased far less, work hours fell 12 percent (OECD 2004, Chapter 1).

\section{Inequality and Speculative Excess}

Productivity gains significantly outpaced wage gains in the periods preceding both crises, resulting in labor's share of total income declining as that of capital increased. Despite a drop in the share of income of those with the highest marginal propensity to consume, growth continued in a positive direction. In both periods, economic growth was, in Kalecki's terms, profit-led as opposed to wage-led.

Lagging wages during the 1920s were due in part to technological innovations that were predominantly laborsaving and concentrated in manufacturing, causing a shift in demand for 
labor away from unskilled toward more skilled labor. ${ }^{9}$ Low-skilled assembly-line workers were being replaced by laborsaving capital while the demand for more skilled workers such as machine repairmen increased, resulting in lower wages for the former relative to the latter (Hall and Ferguson 1998: 21). ${ }^{10}$ Although total manufacturing output increased by 64 percent during the decade, the total number of workers in the sector remained almost constant (Stricker 198384). Consequently, the share of wages in manufacturing revenues declined from 52 percent in 1922 to 43 percent in $1929 .{ }^{11}$ With prices and wages fairly stable, increasing productivity flowed predominantly to corporate profits, increasing them 62 percent, enabling dividends to double. ${ }^{12}$ The result was that the disposable income of the richest one percent of the population rose by 63 percent (Livingston 1994: 114-15).

Similarly, in the three decades preceding 2008, wages lagged due to labor-displacing innovations, as well as increasing international trade that exported significant numbers of manufacturing jobs. ${ }^{13}$

During the 1920s, and the three decades preceding the financial crisis of 2008, the increased share of income and wealth accruing to the elite was far greater than could readily be spent, even on the most lavish consumption. ${ }^{14}$ Thus in both periods an elite had additional saving and they and their money managers sought to place these increased assets to maximum effect. But given the fact that those who spend most or all of their income had a smaller share of total income, profitable investment potential in the real economy was limited. ${ }^{15}$ As a result, funds flowed into the financial sector, where they increased employment by 400,000 between 1925 and 1929 (Stricker 1983-84: 53).

Although new consumer durable goods such as automobiles, refrigerators, electric irons, and radios were driving forces for much of the economic dynamism of the early decades of the 
twentieth century, rapidly rising inequality during the 1920s constrained the demand for these products. Although installment credit permitted consumers to continue increasing their purchases, rising indebtedness meant that this would ultimately be limited by creditworthiness. As Stricker has put it, "Consumption-demand lagged behind potential output of consumption goods, and only installment credit and upper-class consumption smoothed over that problem for a while” (1983-84: 55). In addition, robust increases in productivity further reduced the need to invest in these industries. Investment in plant and equipment declined from \$15.5 billion in 1926 to about $\$ 14.5$ billion annually over the next three years (Stricker 1983-84: 51). Investment in construction also declined in the late 1920s (Stricker 1983-84: 52).

In 1970, the labor share comprised 60 percent of GDP while capital received 24 percent. In 2006, labor's share was 50 percent and capital's 29 percent (BEA NIPA). The resulting inequality meant that an elite had additional saving and they and their money managers sought to place these increased assets to maximum effect. But given the fact that those who spend most or all of their income had a smaller share of total income to spend, profitable investment potential in the real economy was limited. In his memoirs, Alan Greenspan took note of this lack of profitable investment outlets: "intended investment in the United States has been lagging in recent years ...presumably for lack of new investment opportunities” (2007: 387).

In the six years preceding the 2008 crisis, firms were investing less than their retained earnings - the longest period of such business behavior since the Second World War --, even as corporate profits as a share of national income nearly doubled. But these profits soared especially in the financial sector. Whereas financial sector profits have generally constituted about 10-15 percent of corporate profit, they jumped to 40 percent in 2007 (Stiglitz 2008: 36). In response to this profit shift, the finance, insurance, and real estate sector rose from 14.9 percent to 20.6 
percent between 1974 and 2004 (President of the United States 2006, Table B12, 296-97). Major manufacturing firms such as General Motors, Ford, and General Electric developed increasingly powerful financial departments. By 2000, General Electric received more income from financial transactions than from manufacturing. This shift from the productive to the financial sector also shows up in compensation. Average compensation in the financial sector that was close to parity with that of domestic private industries between 1948 and 1982, was 181 percent of higher by 2007 (Johnson 2009).

The financial crisis of 2008 was able to sneak up on the economy because the dominant focus was on surface reality, on the fact, for instance, that between 1991 and 2006 growth averaged 3.22 percent and inflation never went above four percent. However, beneath the surface, dramatically rising inequality was shifting investment from production to finance and speculation.

Prior to both crises, speculative excesses sequentially occurred in two different sectors, albeit in reverse order. In the 1920s, a speculative boom in real estate crashed three years before the stock market crash. In the most recent crisis, a stock market boom, fueled by a high tech craze, crashed before real estate collapsed six years later.

\section{Speculative Fever Leading Up to 1929}

Before World War I, homes were often financed by borrowing from family and friends. But expansion of financial institutions flush with assets and thus offering attractive credit conditions encouraged an increase in institutional borrowing about 45 percent before World War One to about 60 percent by 1925. Mortgage lending increased by 55 percent between 1922 and 1925, fueling a real estate bubble.

The bubble was pricked by the severe September 1926 hurricane, causing widespread 
devastation in Florida where the boom had been most robust (Galbraith 1954). Housing prices that had soared about 20 percent in the early 1920s, declined by about 10 percent before the stock market crash.

Following the collapse of the real estate market, investment funds flowed more aggressively into the stock market, fueled in part by the explosion of investment trusts from about 40 in 1921 to more than 750 in 1929 (Carosso 1970). Toward the end of the 1920s, trusts came to hold the stocks of other leveraged trusts, creating a ponzi-like structure. Galbraith noted that "In 1927 the trusts sold to the public about \$400,000,000 worth of securities; in 1929 they marketed an estimated three billions worth” (1954: 49-50). ${ }^{16}$

In the last few years before the crash, rising interest rates prompted an explosion in loans by corporations to brokers who were able to command higher returns on margin loans to speculators. Hall and Ferguson note that "Loans to brokers totaled \$7.63 billion in 1924 and then

rose to $\$ 26.53$ billion by $1929 .$. while weekly rates on margin loans averaged 8.56 percent... individuals were [receiving] dividends yields averaging 2.92 percent” (1998: 24-25). ${ }^{17}$

\section{Speculative Fever Leading Up to 2008}

The relative lack of new investment opportunities in the real economy prior to 2008 created a premium for financial entrepreneurs devising new financial investment instruments. Traditionally, banks that originated loans held them until maturity, providing good cause to scrutinize well the credit worthiness of the borrowers. What changed is that financial entities began to buy up mortgages and credit card debt and then package them in bonds backed by the monthly payments of the mortgage borrowers and credit card holders. Between 1980 and 2000, this securitized debt expanded 50-fold, whereas bank loans expanded 3.7-fold. By the end of 2007, two-thirds of all private U.S. debt passed through Wall Street (Wilmers 2009: A19). 
Although banks no longer needed to be as cautious as to borrowers' credit risk, "securitization" was widely believed to strengthen the financial system by spreading risk more broadly.

These new tools encouraged more and more wealth to be held in the form of financial assets. Along with the booming high tech stocks of the late 1990s, financial assets seemed the most promising way to make one's wealth grow. Indeed, such instruments as hedge funds seemed a low risk alternative or complement to the sizzling tech stock market.

Nevertheless, with more wealth in the hands of those with less to lose from risky investments, the total amount of wealth held in stocks as a share of total assets more than doubled from 1983 to the crash in 2001 (Wolff, 2004: 11). By holding more wealth in the form of stocks, investors scrambled for ever-higher returns from these investments, generating the tech bubble of the late 1990s. While the bursting of this bubble did have some repercussions on the real sector, because the bubble was mostly limited to the stock market, its impact was primarily felt by those in higher income brackets. In addition, an expanding housing market continued to grow through the bursting of the tech bubble, tempering the severity of the 2001 recession. More and more wealth was redirected into real estate. Between 2001 and 2007, the market value of residential property went up as a percentage of total assets (Bucks 2009, A28).

With a plethora of credit fueled by expansionary monetary policy, inflow of foreign monies, ${ }^{18}$ and greater use of financial instruments, financial institutions sought out less creditworthy customers, with these loans securitized and sold. Lower-income households were sold sub-prime mortgages to purchase housing at increasingly inflated prices. Mortgage lenders saw great short-term gain potential in these skyrocketing housing prices. But when low-income borrowers could not make their mortgage payments, the collapse was assured. ${ }^{19}$ 
What made the crisis of 2008 severe was the breadth of participation. Whereas the percentage of households holding equity in their homes had remained at about 64 percent between 1975 and 1995, this figure stood at over 69 percent by 2008. In a highly deregulated environment, as an elite poured much of its increasing share of income and wealth into the real estate market, an extreme speculator's market evolved (Bucks, 2009: A29).

\section{A Richer Elite's Heightened Command of Ideology}

Given the complexity of shifts in ideology, it is understandably that there would be no clear consensus as to why the political pendulum swung dramatically toward laissez-faire ideology between World War I and 1929 and in the three decades leading up to 2008. Nevertheless, some things stand out. In the first period, the ease with which labor=s failure to fulfill its informal wartime Ano strike@ pledge was depicted as unpatriotic at a time when the Russian Bolsheviks were introducing an alternative to capitalism. In a "Red Scare” environment, labor=s struggles were increasingly portrayed as part of a communist conspiracy, while business interests embarked on a campaign to demonstrate the patriotism of business and the dangers inherent in labor=s intransigence (Watts 1991).

In the more recent shift toward laissez faire ideology, the fact that stagflation delegitimated Keynesian economics enabled the right to nurture and draw upon a virulent strain of neoclassical economics in the form of supply-side economics. Also noteworthy was the loss of gold backing of the dollar and its devaluation, loss of the Vietnam War, and presumed lax discipline and rising moral degeneracy, as evidenced by sexual promiscuity, sloppy attire, and drugs.

Reinforcing these ideological shifts in both periods was the fact that rising inequality meant that the very rich had more resources with which to influence public opinion and policy. 
Different income and wealth groups have different interests and these interests are captured in ideologies that compete in the public sphere. The generation and dissemination of ideology requires resources, and thus the larger share of income and wealth accruing to the wealthy was destined to have ideological and political consequences.

With superior education, and increasing resources, it is understandable that the rich would progressively learn to craft their self-serving ideologies so that they become ever-more convincing to a majority of the electorate. ${ }^{20}$ Their disproportionate control over the media, educational institutions and think tanks makes this outcome inevitable. As they received everlarger shares of national wealth and income, this process was sped up. Research reveals that their expenditures on creating and disseminating ideology yield high returns (Glaeser 2006).

\section{The Surge of Laissez Faire Ideology During the 1920s}

The election of 1920 returned control of the federal government to the Republican party, such that "Business-oriented Republicans dominated national politics and lobbying efforts in Congress” (Edsforth 1998: 246), claiming that the American free-enterprise system promoted the values of Asocial harmony, freedom, democracy, the family, the church, and patriotism.@ Advocates of Agovernment regulation of the affairs of business@ were characterized as subversive (Carey 1995, 27). In an anti-union climate, the courts issued as many anti-labor injunctions during the 1920s as during the entire period from 1880 to 1920 (Bernstein 1966, 2000). The Supreme Court ruled minimum wage legislation in the District of Columbia unconstitutional in 1923. Undergirding these decisions was the doctrine of Afreedom of contract.@ The right of labor to organize was virtually nonexistent and radical organizations were repressed (Edsforth 1998: 247).

A new media technology, the radio, greatly assisted the dissemination of ideology. The 
first regular radio broadcast took place in November 1920. By 1923 more than 500 radio stations operated in the U.S. and 550,000 radio sets were sold that year. In 1928, 12 million sets catered to 40 million listeners (Blanning 2008: 204-05).

So completely did business dominate the climate of opinion during the 1920s that Roger Babson, a powerful investment advisor and founder of Babson College claimed that it had "the press, the pulpit and the schools” (cited in Cochran and Miller 1942: 343-44).

\section{The Resurgent of Laissez Faire Ideology Prior to 2008}

During the three decades leading up to 2008, the media -- newsprint, television, and radio -- became increasingly concentrated in the hands of a few mega corporations, due in significant part to deregulation. For instance, the number of newspapers controlled by chains went up significantly as a result of relaxed ownership regulations (McPherson 2008: 165). Blethen notes that "The majority of our media are controlled by just five companies [such that] About one-third of the population now listens to radio stations owned by a single company....The 1996 deregulation of radio virtually ended local ownership in that medium” (2004: B7). Increased corporate media concentration served to restrict criticisms of laissez-faire ideology and the corporate power structure.

An important component of the increasing influence of conservative, free-market ideology was the proliferation and empowerment of conservative think tanks such that they came to outnumber their liberal counterparts by a ratio of two to one (Rich 2004: 206). By 2006 the Heritage Foundation alone had larger expenses than the largest four liberal think tanks combined. Corporate influence over higher education also dramatically increased (Perelman 2002; Washburn 2005). 
In addition to greater support from think tanks and lobbyists, from the 1970s onward, academic economists provided increasing support to free-market ideology, thereby lending support to right-wing policies, even when such was not their intent. The mainstream economic canon became generally supportive of unfettered and thus unregulated markets, even when the consequence was greater inequality. ${ }^{21}$

Because of an elite's increased command over ideology, the losers - the overwhelming majority of Americans - could not use the political process to stop the super-rich rip-off. Through the democratic process, in principle, they could have forced the creation of compensatory measures to relieve workers harmed by technological change or international trade. Taxes could have been restructured in their favor, and public services that benefit them could have been vastly expanded and improved. However, an elite's increased control over the ideology infrastructure resulted in the majority buying into the rich's ideology that such measures would not be to their own benefit. ${ }^{22}$ As former chief economist at the International Monetary Fund, Simon Johnson, put it, “...the American financial industry gained political power by amassing a kind of cultural capital - a belief system... [such that] the attitude took hold that what was good for Wall Street was good for the country.... Faith in free financial markets grew into conventional wisdom - trumpeted on the editorial pages of The Wall Street Journal and on the floor of Congress” (2009).

\section{Final Reflections}

During the 1920s and the three decades prior to 2008, concern about rising inequality was widely dismissed as either irrelevant or missing the economic dynamism that inequality

generates. ${ }^{23}$ Its irrelevance, much of mainstream economics insisted, was that if everyone is becoming materially better off, the size of shares is unimportant. 
A broader understanding of the scope of what constitutes economic phenomena, however, reveals the myriad ways in which inequality is central to economic processes and even, as this study demonstrates, how its dynamics can set the stage for severe systemic dysfunction. Veblen's theory of consumer behavior reveals how rising inequality generates a struggle to maintain social respectability through augmented consumption. A Keynesian/Kaleckian perspective reveals how rising inequality impairs aggregate demand and redirects investment away from the real economy into financial speculation. Marx’s theory of ideology shows how rising inequality enables an elite to gain increasing control over economic and political ideology. The crisis of 1929 marked a turning point, reversing rising inequality, and ushering in roughly four decades of democratically-driven policies that significantly lessened inequality and made possible what many consider a "golden age” of U.S. capitalism following World War Two. Might the crisis of 2008 promise to have similar long-run distributional and growth-dynamic consequences? Perhaps. As Milton Friedman put it, “Only a crisis—actual or perceived—produces real change (1982: ix). 


\section{REFERENCES}

Bernanke, Ben S. 2000. Essays on the Great Depression. Princeton, New Jersey: Princeton University Press.

Bernstein, Irving. 1966. The Lean Years: A History of the American Worker, 1920-33. Boston: Penguin Books.

Bernstein, Michael A. 1998. “The American Economy of the Interwar Era,” in Calvin Coolidge and the Coolidge Era, John Earl Haynes, ed. Washington, D.C. Library of Congress: 191-213.

Blanning, Tim. 2008. The Triumph of Music. Cambridge Mass.: Harvard University Press.

Blethen, Frank A. 2004. "Stop the Media Mergers,” The Washington Post, September 19: B7.

Bourdieu, Pierre. 1984. Distinction: A Social Critique of the Judgement of Taste. London: Routledge \& Kegan Paul.

Brown, Christopher. 2008. Inequality, Consumer Credit and the Saving Puzzle. Northampton, Mass.: Edward Elgar.

BLS: Current Employment Statistics. 2010 Bureau of Labor Statistics. Accessed May 20, 2010. 
http://www.bls.gov/cps/

Bucks, Brian K., Arthur B. Kennickell, and Kevin B. Moore. 2006. "Recent Changes in U.S. Family Finances: Evidence from the 2001 and 2004 Survey of Consumer Finances.” Federal Reserve Bulletin, vol. 92, February: A1-A38.

Bucks, Brian K., Arthur B. Kennickell, Traci L. Mach, and Kevin B. Moore. 2009. “Changes in U.S. Family Finances: Evidence from the Survey of Consumer Finances.” Federal Reserve Bulletin, vol. 95, February: A1-A55.

Calder, Lendol. 1999. Financing the American Dream: A cultural History of Consumer Credit. Princeton, N.J.: Princeton University Press.

Carey, Alex. 1995. Taking the Risk Out of Democracy. Chicago: University of Illinois Press.

Carosso, Vincent P. 1970. International Banking in America, A History. Cambridge: Harvard University Press.

Cochran, Thomas C., and Wiliam Miller. 1942. The Age of Enterprise: A Social History of Industrial America. New York: Harper.

Easterly, William. 2002. The Elusive Quest for Growth. Cambridge: MIT Press: 265. 
Economic Report of the President of the United States. 2006. Washington, D.C.: U.S. Government Printing Office.

Edsforth, Ronald. 1998. "Made in the U.S.A.: Mass Culture and the Americanization of Working-Class Ethnics in the Coolidge Era," in Calvin Coolidge and the Coolidge Era, John Earl Haynes, ed. Washington, D.C. Library of Congress: 244-72.

Faulkner, Harold Underwood. 1960. American Economic History. $8^{\text {th }}$ ed. New York: Harper and Row.

Frank, Robert H. 2000. “Does Growing Inequality Harm the Middle Class?” Eastern Economic Journal, 26 (3): 253-64.

Frank, Robert. 2007. Falling Behind: How Rising Inequality Harms the Middle Class. Berkeley, CA: University of California Press.

Friedman, Milton. 1962. Capitalism and Freedom. Chicago: University of Chicago Press.

Galbraith, John Kenneth. 1954. The Great Crash 1929. New York: Houghton Mifflin Harcourt.

Glaeser, Edward L. 2006. "Corruption In America," Journal of Public Economics, 90(6-7), Aug: 1053-1072. 
Grebler, Leo, David M. Blank and Louis Winick. 1956. Capital Formation in Residential Real Estate: Trends and Prospects. Princeton: NBER and Princeton University Press.

Greenspan, Alan. 2007. The Age of Turbulence: Adventures in a New World. New York: Penguin Press.

Hall, Thomas E. and J. David Ferguson. 1998. The Great Depression: An International Disaster of Perverse Economic Policies. Ann Arbor: University of Michigan Press.

Hughes, Johnathan. 1987. American Economic History. $2^{\text {nd }}$ ed. Glenview, Ill.: Scott, Foresman and Co.

Johnson, Simon. 2009. “The Quiet Coup,” The Atlantic Monthly Online, Available at http://www.theatlantic.com/doc/200905/imf-advice

Keynes, John Maynard. 1936. The General Theory of Employment, Interest, and Money. New York: Harcourt, Brace \& World, 1965.

Livingston, James. 1994. Pragmatism and the Political Economy of Cultural Revolution, 18501940. Chapel Hill: University of North Carolina Press.

Livingston, James. 2009. “Their Great Depression and Ours,” Challenge, 52 (3), May/June: 3451. 
Long, Clarence D. 1960. Wages and Earnings in the United States, 1860-1890. Princeton: Princeton University Press.

Marx, Karl. 1846. AThe German Ideology@ in Robert C. Tucker, ed., The Marx-Engels Reader. New York: W.W. Norton, 1978, 172, pp. 146-200.

McPherson, James Brian. 2008. The Conservative Resurgence and the Press: The Media's Role in the Rise of the Right. Evanston: Northwestern University Press.

Miringoff, Marque-Luisa and Sandra Opdyke. 2008. America's Social Health: Putting Social Issues Back on the Public Agenda. Armonk, New York: M.E. Sharpe

NIPA: National Income and Product Account (NIPA). 2010. Bureau of Economic Anaysis. Available at http://www.bea.gov/national/nipaweb/SelectTable.asp

OECD: Organization for Economic Cooperation and Development. 2004. OECD Employment Outlook 2004. Paris: OECD.

Olney, Martha L. 1991. Buy Now, Pay Later. Chapel Hill: University of North Carolina.

Perelman, Michael. 2002. Steal this Idea: The Corporate Confiscation of Creativity. New York: Palgrave. 
Pew Research Center 2008. Available at http://people-press.org/report/?pageid=1282, March 27. Economic-discontent-deepens-as-inflation-concerns-rise, February 14.

Phillips, Kevin (interview). 2002. “Too Much Wealth, Too Little Democracy,” Challenge, September/October, 6-20.

Potter Jim. 1974. The American Economy between the World Wars. London: Macmillan Press.

Rawls, John . 1971. A Theory of Justice. Cambridge: Harvard University Press.

Reich, Robert B. 2007. Supercapitalism: The Transformation of Business, Democracy, and Everyday Life, New York: Alfred A. Knopf.

Rich, Andrew. 2004. Think Tanks, Public Policy, and the Politics of Expertise. New York: Cambridge University Press.

Saez, Emmanuel. 2009. “Striking It Richer: The Evolution of Top Incomes in the United States.” (Update with 2007 estimates), Available at http://elsa.berkeley.edu/ saez/saezUStopincomes-2007.pdf

Sobel, Robert. 1968. The Great Bull Market: Wall Street in the 1920s. New York: W.W. Norton and Co. 
Stiglitz, Joseph E. 2008. “Realign the Interests of Wall Street,” Harper's, November, 36-37.

Stricker, Frank. 1983. AAffluence for Whom B Another Look at Prosperity and the Working Classes in the 1920s,@ The Labor History Reader, ed. Daniel J. Leab. Urbana:

University of Illinois Press.

Stricker, Frank. 1983-84. “Causes of the Great Depression, or What Reagan Doesn’t Know About the 1920s,” Economic Forum, 14, winter: 41-58.

Temin, Peter. 1976. Did Monetary Forces Cause the Great Depression? New York: Norton.

Temin, Peter. 1991. Lessons from the Great Depression. Cambridge, Mass.: MIT Press.

Washburn, Jennifer. 2005. University Inc. The Corporate Corruption of American Higher Education. New York: Basic Books.

Watts, Sarah Lyons. Order Against Chaos: Business Culture and Labor Ideology in America 1880 B 1915. New York: Greenwood Press, 1991.

Wenning, Todd. 2008. "What to Sell in This Market,” The Motley Fool, Nov. 21, Available at http://www.fool.com/investing/value/2009/03/02/what-to-sell-in-this-market.aspx 
Western, David L. 2004. Booms, Bubbles and Busts in US Stock Markets. London: Routledge.

White, Eugene N. 1990. “The Stock Market Boom and Crash of 1929 Revisited,” Journal of Economic Perspectives, 4 (2), Spring: 67-83.

Wilkinson, Richard, and Kate Pickett. 2009. The Spirit Level: Why More Equal Societies Almost Always Do Better. London: Allen Lane.

Williamson, Jeffrey G. and Peter H. Lindert. 1980. "Long-Term Trends in American Wealth Inequality," NBER Chapters, in: Modeling the Distribution and Intergenerational Transmission of Wealth, National Bureau of Economic Research, Inc: 9-94.

Wilmers, Robert G. 2009. “Where the Crisis Came From,” The Washington Post, June 27: A19.

Wisman, Jon D. 2009. “Household Saving, Class Identity, and Conspicuous Consumption,” Journal of Economic Issues, 63 (1), March: 89-114.

Wisman, Jon D. and James F. Smith. "Legitimating Inequality: Fooling Most of the People All of the Time,” American Journal of Economics and Sociology (forthcoming April 2011).

Wolff, Edward. 2004. “Changes in Household Wealth in the 1980s and 1990s in the U.S.” Working Paper, The Levy Economics Institute. Available at http://www.levy.org/pubs/wp407.pdf 


\section{FIGURE 1}

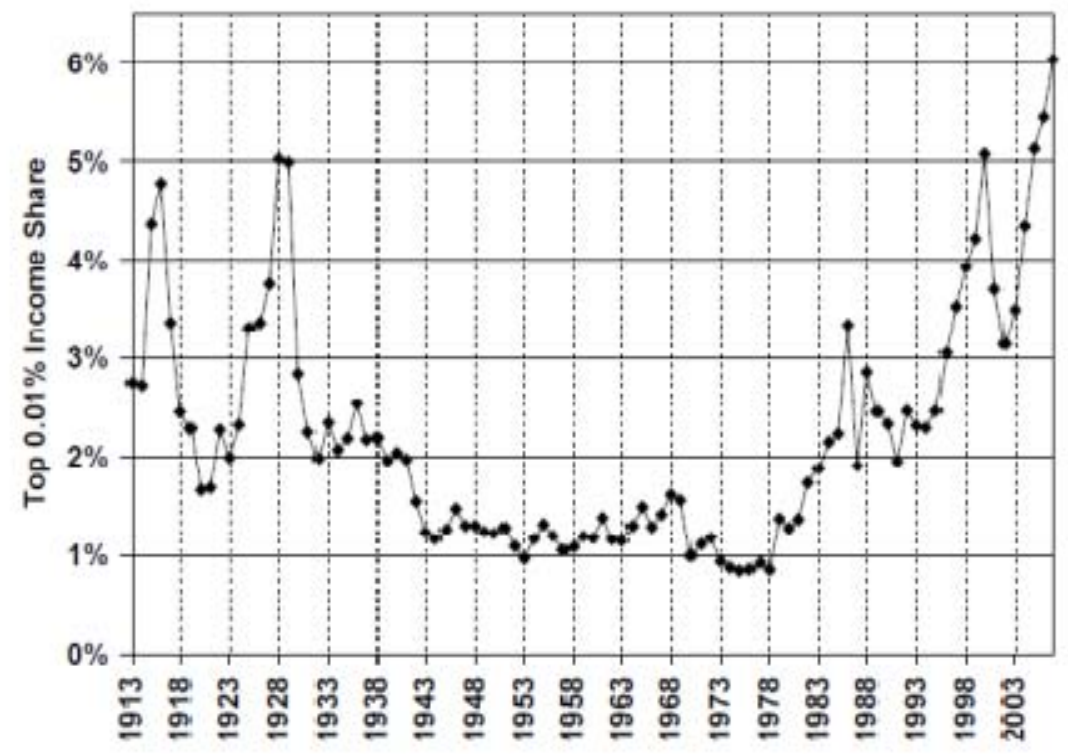

Source:Saez 2009 http://elsa.berkeley.edu/ saez/saez-UStopincomes-2007.pdf 


\section{NOTES}

${ }^{1}$ A glance at highly influential treatises on the Great Depression, e.g., Bernanke (2000) and Temin $(1976$; 1991) finds no mention of a role for inequality in the generation of that crisis. A few exceptions can be found among more heterodox economists, e.g., Hughes 1987, Faulkner 1960, Potter 1974, Livingston 1994, and Stricker 1983-84.

${ }^{2}$ Business spending on advertising increased from \$2.28 billion in 1919 to \$3.43 billion in 1929 (Olney 1991: 137), keeping the consumption practices of the super wealthy ever on display.

3 "Shoestring mortgages" enabled property to be bought on margin. The expansion of such credit instruments unhinged the traditional relationship between income and spending (Olney 1991: 
130-31).

${ }^{4}$ A "free-to-choose" interpretation does not adequately capture the dynamics of this intensified struggle. People do, of course, choose. However, as Robert Frank has noted, their choices are socially constrained:

"Increased spending at the top of the income distribution has not only imposed psychological costs on families in the middle, it has also raised the cost of achieving many basic goals. Few middle-income parents, for example, would be comfortable knowing that their children were attending below-average schools. Yet the amount that any given family must spend to avoid that outcome depends strongly on the amounts that others spend.... [Moreover], people cannot send their children to a public school of even average quality if they buy a home in a school district in which house prices are well below average” (2000: 258).

${ }^{5}$ The argument set forth here is directly opposite that of Keynes (1936: 372-75). For Keynes, an increase in inequality is expected to increase saving since wealthier households have higher marginal propensities to save than do the less-well off. What Keynes failed to take into account is the manner in which rising inequality pressures all households beneath the top to increase consumption to maintain their relative social status. For an extended discussion of Veblen's theory of consumer behavior applied to U.S. saving behavior, see Brown 2008; Wisman 2009.

${ }^{6}$ Calder notes that "By 1930, installment credit financed the sales of 60-75 percent of automobiles, 80-90 percent of furniture, 75 percent of washing machines, 65 percent of vacuum 
cleaners, 18-25 percent of jewelry, 75 percent of radio sets, and 80 percent of phonographs” (1999: 201).

${ }^{7}$ Wenning (2008) notes that much of the debt taken on between 2000 and 2007 was spent on SUVs, huge TVs, granite countertops, and other luxury goods. Increased availability of credit instruments such as credit cards and home equity loans greatly facilitated this emulative consumption (Scott 2007).

${ }^{8}$ Supporting this relationship between inequality and indebtedness, Frank (2007) has found that in those parts of the U.S. where inequality had most risen over a ten-year period, bankruptcy rates also rose most.

${ }^{9}$ There was a high-tech revolution led by companies such as RCA during the 1920s that gave the period a character not unlike the late 1990s (Western 2004: 166).

${ }^{10}$ Williamson and Lindert have estimated that technological innovation during the 1920s increased the premium for skilled labor by 0.98 percent per year (1980: 247).

11 Between 1923 and 1929 weekly earnings declined about 20 percent in manufacturing, and about eight percent in steel production (Bernstein 1966, 66-67). Wages as a percentage of valueadded in manufacturing fell from 45.0 in 1923 to 36.9 in 1929 (Bernstein 1998: 198).

${ }^{12}$ Suggesting a dearth of good investment options for retained earnings, dividends as a share of 
national income rose from 4.3 percent in 1920 to 7.2 percent 1929 . About 82 percent of these dividends were paid to the wealthiest 5 percent of Americans (Hall and Ferguson 1998: 21).

${ }^{13}$ Manufacturing represented 21.2 percent of GDP in 1974, but only 12.1 percent in 2004 (Economic Report of the President 2006: Table B12, 296-97).

14 According to Hall and Ferguson, between 1922 and 1929, "the share of wealth held by the top 1 percent of adults rose from 32 percent to 38 percent. In 1922 the top 1 percent of income recipients accounted for 49 percent of total U.S. saving; by 1929 they accounted for 80 percent of saving” (1998: 21).

15 Hall and Ferguson argue that the mild deflation during the 1920s (an average of about 0.5 percent per year between 1921 and 1929 was traceable to the fact that the expansion in aggregate supply outpaced increases in aggregate demand (1998: 18).

${ }^{16}$ Galbraith reported that, in a population of 120 million, only one and a half million "had an active association of any sort with the stock market” (1954: 78).

${ }^{17}$ Bernstein claims that "Margin-buying was the rule not the exception [and] brokers often allowed as much as 80 percent of the value of a stock purchase to be borrowed... frequently extended in the absence of any formal check on the credit-worthiness of the customer involved” (1998: 197). 
${ }^{18}$ Prior to both crises, foreign funds flowed into the U.S., helping fuel credit expansion. Leading up to 1929, the U.S. and France required that Germany pay its war reparations in gold, creating a net gold inflow into the U.S. and increasing the availability of credit (Bernstein 1998: 204). Leading up to 2008, the underinvestment in the goods-producing sector led to a weak export sector and increasing imports, generating an increasingly large trade deficit. These dollars abroad flowed back into the U.S. financial system, helping keep interest rates low and fueling profitability, while impeding the value of the dollar from substantially falling, thereby allowing the trade deficit to grow further as exports remained expensive and imports cheap.

${ }^{19}$ Financial innovation fueling the housing boom before the 2008 financial crisis included adjustable-rate mortgages, interest-only loans, 100 percent-plus mortgages. Other financial innovations included mortgage-backed securities, derivatives, credit default swaps, and exotics. A bubble in the derivatives market was fueled by the housing bubble.

${ }^{20}$ Veblen believed that because the elite are emulated, their ideology would carry special weight: “The fact that the usages, actions, and views of the well-to-do leisure class acquire the character of a prescriptive canon of conduct for the rest of society, gives added weight and reach to the conservative influence of that class. It makes it incumbent upon all reputable people to follow their lead” (Veblen 1899: 200).

${ }^{21}$ For a discussion of the manner in which economic science has served to legitimate inequality, see Wisman and Smith (forthcoming). 
${ }^{22}$ As former secretary of labor, Robert Reich asserts, “As inequality has widened, the means America once used to temper it - progressive income taxes, good public schools, trade unions that bargain for higher wages - have eroded” (2007: 4).

${ }^{23}$ This claim, however, has not withstood critical scrutiny (e.g., Easterly 2002). 